\title{
Simple ecological trade-offs give rise to emergent cross-ecosystem distributions of a coral reef fish
}

\author{
Monique G. G. Grol • Ivan Nagelkerken • \\ Andrew L. Rypel · Craig A. Layman
}

Received: 22 March 2010/Accepted: 21 October 2010/Published online: 12 November 2010

(C) The Author(s) 2010. This article is published with open access at Springerlink.com

\begin{abstract}
Ecosystems are intricately linked by the flow of organisms across their boundaries, and such connectivity can be essential to the structure and function of the linked ecosystems. For example, many coral reef fish populations are maintained by the movement of individuals from spatially segregated juvenile habitats (i.e., nurseries, such as mangroves and seagrass beds) to areas preferred by adults. It is presumed that nursery habitats provide for faster growth (higher food availability) and/or low predation risk for juveniles, but empirical data supporting this hypothesis is surprisingly lacking for coral reef fishes. Here, we investigate potential mechanisms (growth, predation risk, and reproductive investment) that give rise to the distribution patterns of a common Caribbean reef fish species, Haemulon flavolineatum (French grunt). Adults were primarily found on coral reefs, whereas juvenile fish only occurred in non-reef habitats. Contrary to our initial expectations, analysis of length-at-age revealed that growth rates were highest on coral reefs and not within nursery
\end{abstract}

Communicated by Øyvind Fiksen.

M. G. G. Grol · I. Nagelkerken ( $\square)$

Department of Animal Ecology and Ecophysiology, Institute for Water and Wetland Research,

Radboud University Nijmegen, Heyendaalseweg 135, P.O. Box 9010, 6500 GL Nijmegen, The Netherlands

e-mail: i.nagelkerken@science.ru.nl

A. L. Rypel

USDA Forest Service Stream Hydrology Lab,

Biology Department, The University of Mississippi,

1000 Front Street, Oxford, MS 38655, USA

\section{A. Layman}

Marine Sciences Program, Department of Biological Sciences,

Florida International University, $3000 \mathrm{NE}$ 151st Street,

North Miami, FL 33181, USA habitats. Survival rates in tethering trials were $0 \%$ for small juvenile fish transplanted to coral reefs and $24-47 \%$ in the nurseries. As fish grew, survival rates on coral reefs approached those in non-reef habitats (56 vs. $77-100 \%$, respectively). As such, predation seems to be the primary factor driving across-ecosystem distributions of this fish, and thus the primary reason why mangrove and seagrass habitats function as nursery habitat. Identifying the mechanisms that lead to such distributions is critical to develop appropriate conservation initiatives, identify essential fish habitat, and predict impacts associated with environmental change.

Keywords Connectivity - Life history traits .

Predator-prey dynamics · Nursery .

Ontogenetic niche shifts

\section{Introduction}

Trade-offs between maximizing growth and minimizing predation risk are one of the unifying themes in ecological research (Stephens and Krebs 1986). Evidence of behavioral strategies to minimize the ratio of mortality to growth rate exists for a diverse suite of taxa (Lima and Dill 1990; Dahlgren and Eggleston 2000; Heithaus et al. 2007; Atkinson et al. 2008), and is commonly used in ecological studies to yield insight on how organisms maximize their fitness (Werner and Anholt 1993; Dahlgren and Eggleston 2000; Haywood and Kenyon 2009). Body size is one of the primary factors regulating such trade-offs (Werner and Gilliam 1984). Through ontogeny, foraging strategies and vulnerability to predators can change, and thus the optimal habitat or ecosystem to maximize an individual's fitness may shift dramatically. This well-developed body of 
ecological research focuses primarily on within-ecosystem shifts among localized habitat types, e.g., the foundational example of a fish shifting between littoral and pelagic habitats through ontogeny (Werner and Hall 1988).

Ecosystems are intricately linked by the flow of organisms across their boundaries (Polis et al. 1997; Post et al. 2006; Schreiber and Rudolf 2008), yet it is often difficult to elucidate the mechanisms underlying across-ecosystem movements. For instance, many coral reef fish populations are purportedly supported by the movement of individuals from spatially segregated juvenile habitats (i.e., nursery habitats such as mangroves and seagrass beds; e.g., Verweij et al. 2008), and such connectivity can be essential to the structure and function of the linked ecosystems (Mumby et al. 2004; Mumby and Hastings 2008). As with other examples of broad-scale, across-ecosystem movements by individuals through ontogeny, the underlying mechanisms driving these patterns are difficult to isolate.

"Nursery" is a term with a central place in the marine literature, and generally refers to an ecosystem (or habitat) that supplies a large proportion of individuals to a spatially separated adult population (Adams et al. 2006). Following the framework presented by Beck et al. (2001), the nursery function of an ecosystem or habitat incorporates a combination of four factors (i.e., a higher density, growth, survival, and degree of movement to adult habitats). Although definitions and applications of the nursery concept vary, and are still emerging (Faunce and Layman 2009), the interplay between growth and survival comprises a foundation for assigning particular habitats as nurseries.

Cross-ecosystem linkages between purported nurseries and coral reefs typically are inferred from distributional patterns of constituent organisms. For example, Mumby et al. (2004) provided compelling indirect evidence of connectivity by comparing fish densities on coral reefs with and without adjacent mangrove ecosystems. Other studies likewise provided strong inferential evidence of such linkages between purported nursery habitats and coral reefs (Nagelkerken et al. 2000; Dorenbosch et al. 2005, 2006). Such patterns may be due to the balance of growth and predation risk for juveniles and adults. Juveniles may increase their fitness in purported nursery habitats through higher growth rates as a result of high densities of prey (Fig. 1a; Cocheret de la Morinière et al. 2003; Nakamura and Sano 2005; but see Grol et al. 2008), increased survival due to a lower predation pressure (Fig. 1b; Shulman 1985; Chittaro et al. 2005; Dorenbosch et al. 2009), or a combination of the two (Fig. 1c; Beck et al. 2001). Or since foraging strategies and vulnerability to predators can change during ontogeny, habitat selection may also depend on specific growth/predation trade-offs (Fig. 1d; Dahlgren and Eggleston 2000). Typically, a combination of faster growth and lower predation risk (Fig. 1c) is presumed to underlie the importance of nursery habitats, but empirical data supporting this model for reef fishes remains surprisingly lacking.

In the present study, we examined potential underlying mechanisms that give rise to distribution patterns of a coral reef fish through ontogeny. Because of frequent (i.e., daily) fine-scale movements of fishes among non-reef habitats (Verweij and Nagelkerken 2007), it is often hard to isolate predation risk, growth rates, and maturation of individuals separately in mangroves and seagrasses. Our study location provided an opportunity, however, to compare two spatially segregated ecosystems that harbored several of such habitats. For this purpose we studied: (1) a sheltered shallow-water inland bay harboring adjacent and interconnected non-reef habitats, such as mangroves and seagrasses, which can be divided into a central part of the bay and a long channel which connects the central part of the bay with the open sea; and (2) a fringing coral reef located outside of the bay proper. We hypothesized that fish species utilize bay habitats as juveniles to maximize their growth rates and to minimize predation risk (Fig. 1c). Our model study organism was the French grunt, Haemulon flavolineatum, a common Caribbean fish species that typically lives on coral reefs as adults. Our approach included extensive surveys of $H$. flavolineatum, quantification of growth rates and reproductive investment, and in situ estimation of relative predation risk through ontogeny. The end product is a detailed explanation of potential mechanisms underlying across-ecosystem shifts, and thus
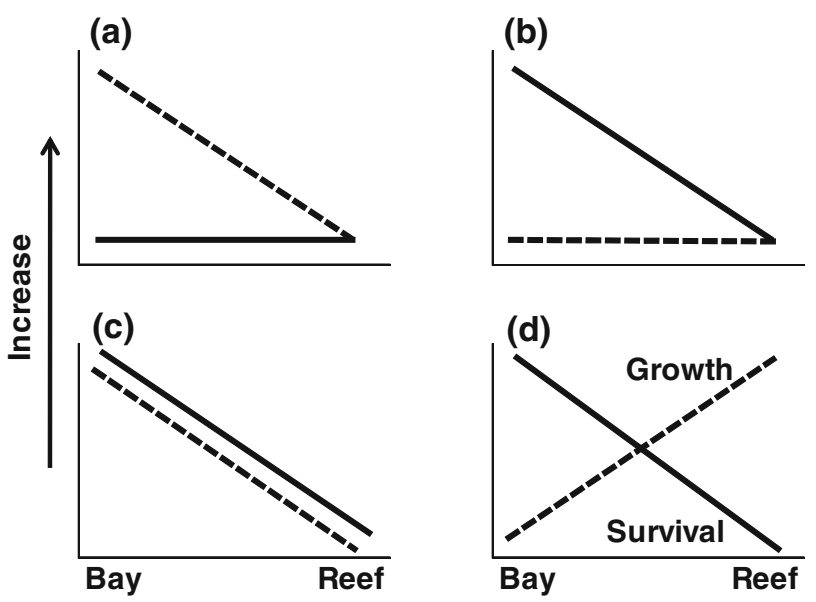

Fig. 1 Conceptual models of underlying mechanisms that explain the use of coastal nursery habitats by juvenile fish in terms of fish growth (dashed lines) and survival (solid lines). a Growth rate is higher in nursery habitats (i.e., the bay) while survival is equal among bay and reef, $\mathbf{b}$ survival is higher in the bay while growth is equal among bay and reef, or $\mathbf{c}$ both survival and growth are higher in the bay than on the reef (the most commonly assumed scenario for coral reef fishes in nursery habitats). d A potential trade-off between predation risk and growth rates in the two ecosystems 
empirical data elucidating why nursery habitats play a critical role in the life history of this coral reef fish.

\section{Materials and methods}

\section{Study area}

In the present study, fish density, growth, predation risk, and reproductive investment of Haemulon flavolineatum were studied in two spatially separated and distinct ecosystems: non-reef habitats in an inland marine embayment-Spanish Water Bay on Curaçao $\left(12^{\circ} 04^{\prime} \mathrm{N}\right.$, $68^{\circ} 51^{\prime} \mathrm{W}$ ) — and on the adjacent fringing coral reef (Fig. 2). The mouth of this sheltered bay is $\sim 80 \mathrm{~m}$ wide and protected by a sill with a maximum depth of $6 \mathrm{~m}$. A relatively long $(1.1 \mathrm{~km})$ channel connects the open sea at the mouth of the bay with the central part of the bay. For further details on Spanish Water Bay, see Nagelkerken et al. (2000). Throughout this study, a clear spatial distinction was made (Fig. 2) among non-reef habitats located in the central part of Spanish Water Bay (referred to as 'bay'), non-reef habitats located between the central part of the bay and the mouth of the Spanish Water Bay (referred to as 'channel'), and the fringing coral reef which is located directly in front of Spanish Water Bay (referred to as 'reef'). Seagrass beds (Thalassia testudinum) and stands of fringing mangroves (Rhizophora mangle) are found along the shorelines of both the bay and channel, while habitats consisting of hard bottom substratum (i.e., rubble, boulders, and notches) are only found in the channel. The fringing coral reef in front of Spanish Water Bay runs along the entire south-west coast of the island.

\section{Distribution patterns}

Density and total length (TL) of $H$. flavolineatum were estimated along permanent belt transects (July-November 2005) in four different habitats throughout the three focal areas (i.e., bay, channel, and reef) using SCUBA and snorkeling gear (see Nagelkerken et al. 2000 for details on census methodology). Transects were separated by at least $25 \mathrm{~m}$, and each transect was $25 \mathrm{~m}$ long $\times 4 \mathrm{~m}$ wide, where possible. Per habitat type, 2-3 sites were selected, and per site, 2-8 permanent transects were placed depending on the size of the habitats. Transects were surveyed 6-8 times during the study period, at least once every 10 days. The estimated TL during visual surveys were converted to fork lengths (FL) using a linear regression $(y=0.884 x+$ $0.147, R^{2}=0.996$ ) based on TL and FL of $481 \mathrm{H}$. flavolineatum caught in the bay, channel, and reef (size range $2.4-16.9 \mathrm{~cm}$ FL, 2.9-18.6 cm TL). Fish counts of H. flavolineatum were then grouped for the bay, channel,

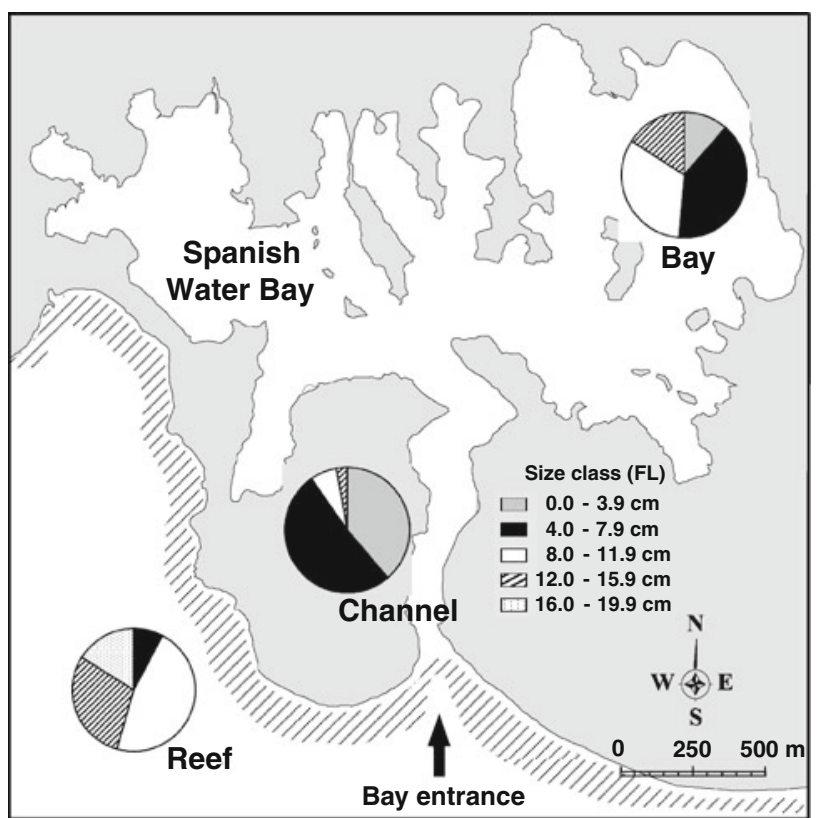

Fig. 2 Distribution of Haemulon flavolineatum in the bay and channel areas of Spanish Water Bay, and on the fringing coral reef on Curaçao based on a 5-month census period. Gray indicates land, white indicates sea, and the hatched area indicates coral reef. Relative fish densities are represented based on 4-cm size classes $(F L)$ in pie charts

and reef separately and averaged over time, number of transects, and habitats, and normalized to a $100-\mathrm{m}^{2}$ census surface area per 4-cm size class (i.e., 0.0-3.9, 4.0-7.9, 8.0-11.9, 12.0-15.9, and 16.0-19.9 cm FL). In total, 95 bay, 336 channel, and 76 reef transects were surveyed.

\section{Growth rates}

Haemulon flavolineatum were captured using hook and line, fish traps, and beach seine nets in the bay, channel, and reef. Fork length was measured, otolith sagittae were removed and the left otolith used for age determination under a dissecting microscope utilizing reflected light (DeVries and Frie 1996). In total, otoliths of 72 bay, 123 channel, and 108 reef fish were analyzed. Ages were determined blindly (e.g., with no knowledge of the sample number or fish size) twice by an experienced reader, and disagreements between reads one and two (4\% of all samples) were settled using another experienced reader. Fish growth was modeled using the Von Bertalanffy Growth Function (Von Bertalanffy 1938), $L_{t}=L_{\infty}\left[1-\mathrm{e}^{-k\left(t-t_{0}\right)}\right]$, where $L_{\mathrm{t}}$ length at time $t, L_{\infty}$ the theoretical maximum length, $k$ a growth coefficient (the rate at which length approaches $L_{\infty}$ ), $t$ fish age in years, and $t_{0}=$ theoretical time at age 0 . Likelihood ratio tests were used to evaluate differences in Von Bertalanffy growth curves among the bay, channel, and reef (Kimura 1980). 
Best-fitting Von Bertalanffy growth curves were calculated separately for bay, channel, and reef using mean length at each age class. Then, a best fitting curve was calculated by combining all individuals from the three focal areas being compared (i.e., coincident curves). Von Bertalanffy growth curve fits (analyzed by the residual sum of squares; Kimura 1980; Haddon 2001) were sequentially compared across bay, channel, and reef. If the improvement in fit for each comparison was significant [relative to the chi-squared $\left(\chi^{2}\right)$ distribution] then growth was considered to be significantly different between bay, channel, and reef (Haddon 2001). Fish caught on the reef of 2 years and older may consist of individuals that have spent their juvenile stage in Spanish Water Bay and subsequently migrated to the coral reef. In such case, their growth history reflects a mix between growth in the bay, channel, and reef. Thus, we compared growth among the bay, channel, and reef using fish from the bay and channel and fish that likely have only lived on coral reefs, i.e., those of 0 and 1 year old. To test for differences in size-at-age for year 1 fish among bay, channel, and reef, a one-way ANOVA followed by a Hochberg's GT2 post hoc comparison test was performed. A Hochberg's GT2 post hoc test was used because data were homogenous (Levene's test, $P \geq 0.050$ ) and sample sizes unequal (Field 2005). For year 0 fish, only one fish was caught in the bay, and therefore only two study areas (i.e., channel and reef) could be compared performing an independent samples $t$ test (Field 2005).

\section{Survival rates}

Relative predation risk on tethered $H$. flavolineatum was estimated in the bay, channel, and reef during the day at the same locations where visual surveys were conducted. Tethering trials were conducted for three life stages: recently settled fish (2.4-4.5 cm FL), approximate size at which fish start migrating to reefs $(8.1-12.0 \mathrm{~cm}$ FL), and adult fish commonly found on reefs (13.8-16.9 cm FL). Tethering was used to measure relative predation risk among bay, channel, and reef for different size classes. We did not intend to measure absolute rates of predation, but to assess the effect of location (bay, channel, and reef) and prey size on predation risk. Although tethering experiments can produce biases that can confound results (Peterson and Black 1994), it is a widely used method to measure relative predation risk on a diverse suite of fish and invertebrate prey species (Shulman 1985; Pile et al. 1996; Dahlgren and Eggleston 2000; Halpin 2000; Baker and Sheaves 2007; Rypel et al. 2007; Dorenbosch et al. 2009; Hammerschlag et al. 2010). In addition, tethering experiments were conducted during daytime, while various studies suggest that many piscivores are nocturnally active and/or piscivore fish assemblages may change at night (Dorenbosch et al. 2009 and references therein). However, the same tethering method was used across the bay, channel, and reef and for the different size classes, and possible tethering artifacts among treatments were expected to be relatively consistent (e.g., Aronson and Heck 1995).

Individual fish were secured to a thin, monofilament, tether line (50-80 cm length) using a small hook on one end of the line which was threaded through the lower jaw with the other end attached to an iron pole $(\sim 40 \mathrm{~cm})$ that was pushed into the substratum. Each fish was able to swim and hide within surrounding vegetation (when present). Tethering was conducted along the same transect sites in the bay, channel, and reef as those for the visual surveys, and lasted $90 \mathrm{~min}$. The sequence of tethering was done randomly across the different sites and size classes in the bay, channel, and reef. Only fish that survived and were alive ( $n=145)$, or that had clearly been attacked or eaten (i.e., hook and/or part of the line missing, $n=162$ ) at the end of the trial, were considered successful trials and were included in the analyses; dead $(n=17)$ and possibly detached fish (i.e., line and hook undamaged, $n=53$ ) were excluded. The total number of successful trials ranged from 10 to 17 fish per site for each of the two smaller size classes and 6-7 fish per site for the largest size class. Percent survival at the end of the experiment (at $90 \mathrm{~min}$ ) was averaged across replicates per size class per site, separately for bay, channel, and reef. Differences in survival among bay, reef, and channel were compared using logistic regressions and post hoc $\chi^{2}$ tests with survival ( 0 or 1$)$ as a dependent variable, and size class as an independent variable. In total, 127 bay, 115 channel, and 65 reef trials were included in the analysis.

\section{Reproductive investment}

Reproductive investment was determined on basis of the relationship between body and gonad weight (Ntiba and Jaccarini 1990; Kulmiye et al. 2002). Therefore, gonad pairs were collected from fish caught in the bay, channel, and on the reef. Wet weight of both fish gonads was weighed with an accuracy of $0.001 \mathrm{~g}$ and was used to calculate the gonadosomatic index $(\mathrm{GSI}), \mathrm{GSI}=(\mathrm{GW} / \mathrm{BW}) \times 100$, where $\mathrm{GW}$ is the wet weight of both gonads and BW the eviscerated wet body weight of the fish. In total, GSI of 77 bay, 323 channel, and 200 reef fish were calculated. Mean GSI was calculated per 4-cm size class (FL), separately per bay, channel, and reef. To explore differences among the three focal areas per size class one-way ANOVAs were performed followed by Hochberg's GT2 post hoc comparisons if data had homogeneous variances (Levene's test, $P \geq 0.050$ ) and unequal sample sizes (Field 2005). If variances were non-homogeneous (Levene's test, $P<0.050$ ) a non-parametric KruskalWallis test followed by a Games Howell post hoc 
comparison was used (Field 2005). Note that for size class 0.0-3.9 cm FL, fish were only caught in the channel and on the reef, but no statistics could be computed because $\mathrm{GSI}=0.0$ for all fish captured.

All statistical analyses were performed using SPSS (version 15.0), and differences were significant if $P$ values were $\leq 0.050$.

\section{Results}

\section{Distribution patterns}

In Spanish Water Bay, smaller fish inhabited the bay and channel, whereas larger-sized fish typically were found on the reef (Fig. 2). In the channel, recently settled $(0.0-3.9 \mathrm{~cm} \mathrm{FL})$ and other small individuals $(4.0-7.9 \mathrm{~cm}$ FL) were most common. Within the bay, small to sub-adult individuals were most common $(4.0-11.9 \mathrm{~cm}$ FL). The $12.0-15.9 \mathrm{~cm}$ FL size class was most abundant on the reef, and individuals of the largest size class (16.0-19.9 cm FL) were only present on the reef.

\section{Growth rates}

Von Bertalanffy growth models (Fig. 3) showed that Haemulon flavolineatum from the reef reached larger sizes $\left(L_{\infty}=18.7 \mathrm{~cm}\right.$ FL) than fish in the other two areas, with same-aged fish from the reef $\sim 1.3$ times the maximum size of fish from the bay $\left(L_{\infty}=14.1 \mathrm{~cm} \mathrm{FL}\right)$ or from the channel $\left(L_{\infty}=14.3 \mathrm{~cm} \mathrm{FL}\right)$. Fish growth based on otolith ageing of $H$. flavolineatum was significantly faster on the coral reef than in the bay or channel (Fig. 3; likelihood ratio test of coincident curves for bay-reef, $\chi^{2}=43.73$, $P<0.0001$, and channel-reef, $\chi^{2}=37.66, P<0.0001$ ). Furthermore, growth was significantly faster in the bay than in the channel (bay-channel, $\chi^{2}=42.48, P<0.0001$ ). Year 0 fish were significantly larger on the reef compared to the channel (independent samples $t$ test, $t_{63}=-2.21$, $P=0.031$ ). Year 1 fish differed in growth (one-way ANOVA, $\left.F_{2,94}=30.51, P<0.0001\right)$ and were significantly larger on the reef compared to the bay (Hochberg's GT2, $P<0.0001)$ and the channel $(P<0.0001)$. Within Spanish Water Bay, year 1 fish were significantly larger in the bay than fish in the channel $(P=0.002)$.

\section{Survival rates}

On the reef, no small fish (2.4-4.5 cm FL) survived the 90min tethering trials, while in the bay $47 \%$, and channel $24 \%$, survived (Fig. 4). Survival differed for this size class (Logistic $R^{2}=0.31,-2 \log$ (likelihood) $=29.4, P<$ $0.0001)$ and was significantly higher in the bay compared

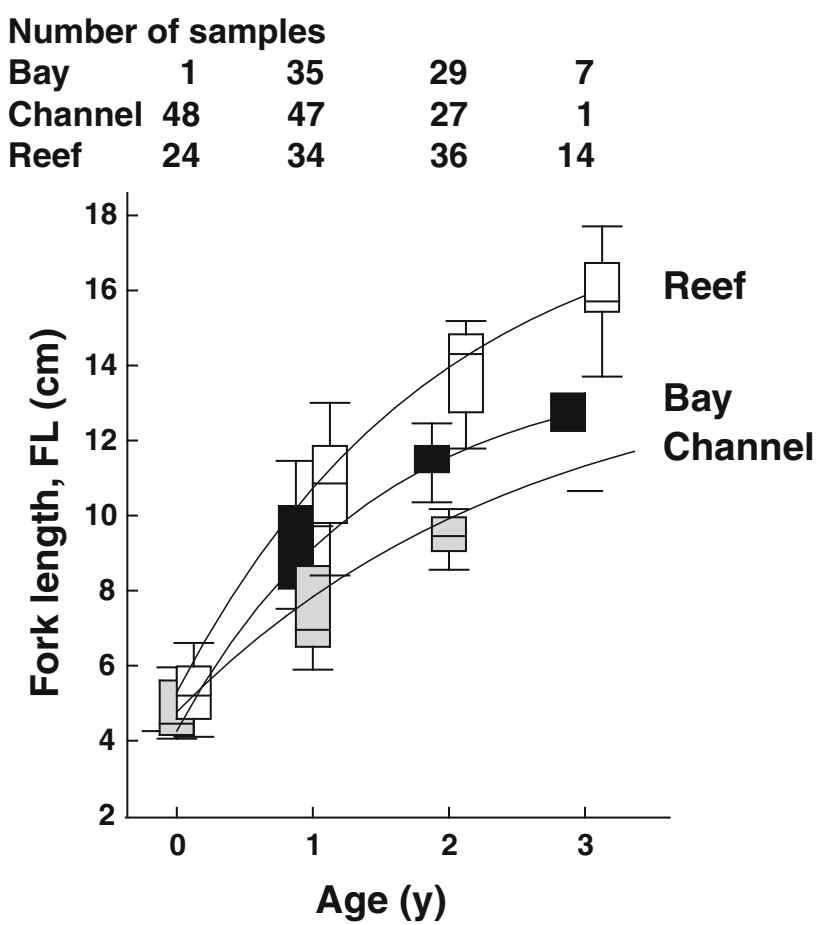

Fig. 3 Von Bertalanffy growth curves for Haemulon flavolineatum in the bay (black boxes) and channel (gray boxes) areas of Spanish Water Bay and on the reef (open boxes) on Curaçao. Box plots for each age class are jittered for visibility. Note that the black box for year 0 fish and the gray box for year 3 fish are absent as $n=1$ in each case. Von Bertalanffy parameters for $H$. flavolineatum were $L_{\infty}=14.1, t_{0}=-0.53$, and $k=0.69$ for the bay; $L_{\infty}=14.3$, $t_{0}=-1.05$, and $k=0.39$ for the channel; and $L_{\infty}=18.7, t_{0}=$ -0.64 , and $k=0.52$ for the coral reef. The number of otoliths sampled per area per age class is provided above the graph

to the channel $\left(\chi_{(1)}^{2}=7.60, P=0.006\right)$ and to the reef $\left(\chi_{(1)}^{2}=6.76, P=0.009\right)$. Between channel and reef, no significant difference was found. Survival for tethered fish between $8.1-12.0 \mathrm{~cm} \quad$ FL (Logistic $R^{2}=0.20, \quad-2$ $\log ($ likelihood $)=18.0, \quad P<0.0001) \quad$ was significantly lower on the reef compared to the bay $\left(\chi_{(1)}^{2}=12.48\right.$, $P<0.0001)$ and to the channel $\left(\chi_{(1)}^{2}=10.07, P=0.002\right)$. Between bay and channel there was no significant difference. Survival increased with size, and for fish 13.8-16.9 cm FL survival on the reef $(56 \%)$ approached those of non-reef habitats (channel $77 \%$ and bay 100\%). Survival (Logistic $R^{2}=0.32,-2 \log ($ likelihood $)=15.2$, $P=0.001$ ) after $90 \mathrm{~min}$ did not significantly differ between the channel and reef and channel and bay, but was significantly higher in the bay compared to the reef $\left(\chi_{(1)}^{2}=3.91, P=0.048\right)$.

Reproductive investment

Smaller fish $(<12.0 \mathrm{~cm}$ FL) did not show a significant difference for GSI among the three focal areas, but larger 


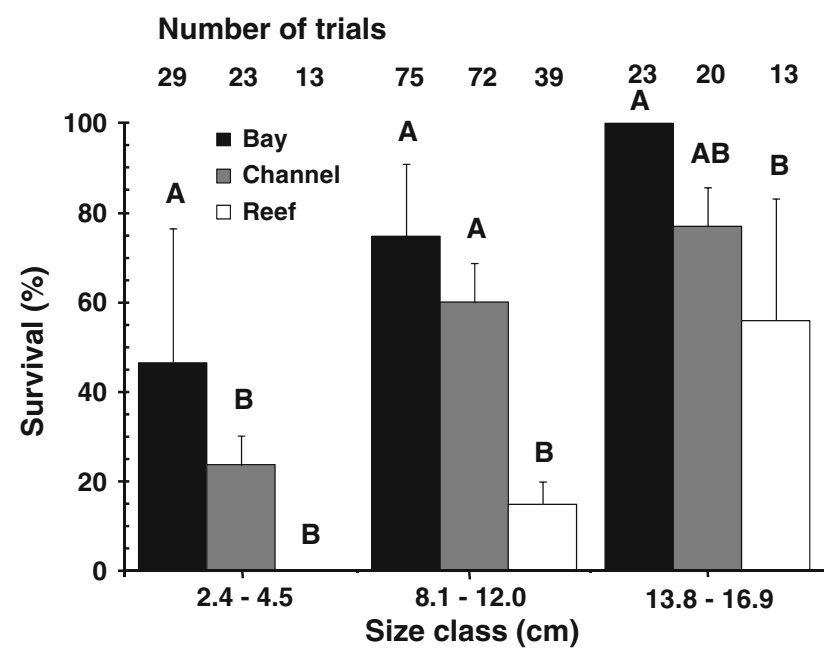

Fig. 4 Survival from predation after $90 \mathrm{~min}$ in tethering trials (mean $+\mathrm{SE})$ of Haemulon flavolineatum for three different life stages in the bay (black bars) and channel (gray bars) areas of Spanish Water Bay and on the fringing coral reef (open bars) on Curaçao. Size ranges of tethered fish were chosen to represent the following life stages: recently settled fish (2.4-4.5 cm FL), approximate size at which fish start migrating to reefs $(8.1-12.0 \mathrm{~cm} \mathrm{FL})$, and adult fish commonly found on reefs (13.8-16.9 cm FL). Within each size class, different letters indicate significant differences $(P \leq 0.05)$ among areas based on a logistic regression. No fish $2.4-4.5 \mathrm{~cm}$ FL survived the tethering trails after 90 min on the reef, while all fish 13.8-16.9 $\mathrm{cm}$ FL survived the 90-min tethering trials in the bay. The number of successful tethering trials per area per size class is provided above the graph

fish ( $\geq 12.0 \mathrm{~cm}$ FL) did (Fig. 5). Gonads of larger fish $(12.0-15.9 \mathrm{~cm}$ FL) residing on the reef were further developed and GSI (Kruskal-Wallis $H_{2}=19.12$, $P<0.0001)$ was higher on the reef compared to the channel (Games Howell, $P=0.010$ ) and to the bay $(P<0.0001)$. Within Spanish Water Bay, GSI of fish residing in the channel was significantly higher than fish in the bay $(P=0.012)$. The highest GSI was found for the largest-sized fish on the reef (16.0-19.9 cm FL).

\section{Discussion}

It has become an accepted paradigm that mangroves and seagrass beds in embayments are preferred settlement and juvenile habitats, as they provide high food availability (and thus purportedly faster growth rates) and lower predation risk (higher survival rates) for many coral reef fish species (Fig. 1c; Beck et al. 2001; Adams et al. 2006). Yet, empirical studies providing support for this well-accepted paradigm are surprisingly rare, calling into question the basic assumptions regarding nursery habitats for coral reef fishes. In our study, juvenile grunts $(<8 \mathrm{~cm}$ FL) were found in the highest densities in the bay and channel where relative predation risk was apparently lower than on the reef.

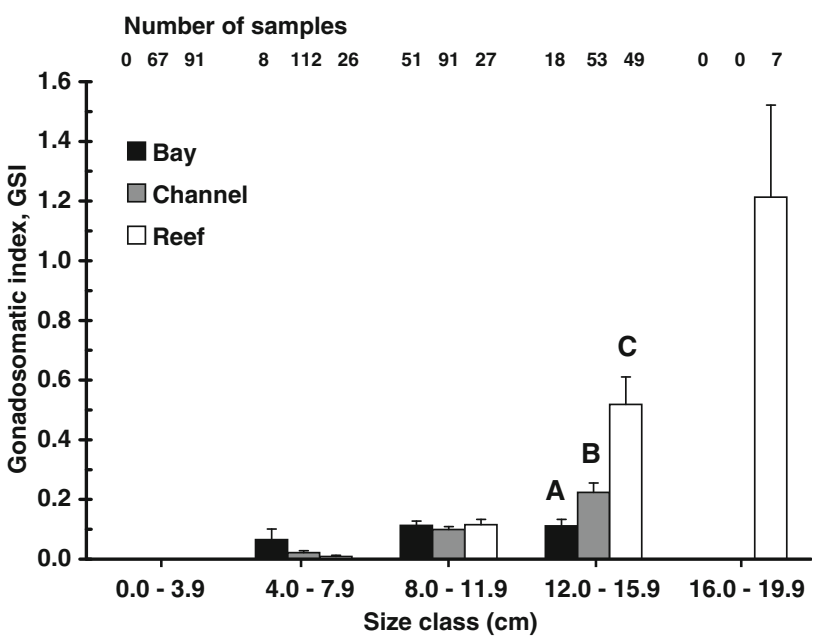

Fig. 5 Gonadosomatic index, GSI (mean + SE) of Haemulon flavolineatum per 4-cm size class FL in the bay (black bars) and channel (gray bars) areas of Spanish Water Bay and on the reef (open bars) on Curaçao. Within each size class, different letters indicate significant differences $(P \leq 0.05)$ among areas based on a one-way ANOVA followed by a Hochberg's GT2 post hoc comparison or a nonparametric Kruskal-Wallis test followed by a Games Howell post hoc comparison. The number of fish sampled per area per size class is provided above the graph

The trade-off, however, was a reduced growth rate, body size, and thus slower sexual maturation (Fig. 1d). Our data provide strong support that predation intensity, not increased growth potential, ultimately gives rise to the apparent nursery function of mangroves and seagrass beds in embayments for this species. Such empirical data is critical to understanding the mechanisms that give rise to across-ecosystem distribution patterns and ontogenetic habitat shifts in marine organisms.

Although differences in growth and survival were most obvious between the reef and Spanish Water Bay, these factors also showed more subtle differences in the latter system. Within Spanish Water Bay, the highest densities of fish $<8 \mathrm{~cm}$ FL were found in the channel, with the smallest individuals $(0.0-3.9 \mathrm{~cm}$ FL) mainly in the mouth of Spanish Water Bay (Grol 2010). Thus, by settling in the channel away from the reef, fishes increased their survival rate considerably compared to the reef, but at the detriment of growth. For larger individuals $(\geq 8 \mathrm{~cm}$ FL), relative predation risk was similar between channel and bay, but growth rate and density were higher in the bay. This suggests that, once fish have entered a bay environment with lower predation risk compared to reefs, other mechanisms give rise to distribution patterns among nursery habitats (e.g., food abundance, shelter quality, local physio-chemical factors, etc.).

Larger Haemulon flavolineatum shifted from the bay and channel to the reef at $\sim 12.0 \mathrm{~cm}$ FL, which could be related to ontogenetic changes in vulnerability to predation 
(Werner and Gilliam 1984; Hixon 1991; Laegdsgaard and Johnson 2001). Our data showed that predation risk was similar between bay and channel and between channel and reef for larger-sized $H$. flavolineatum. Despite higher densities of potential predators on the reef, predator gapelimitations may render $H$. flavolineatum less susceptible to predation (Mumby et al. 2006). This is especially true for overfished predator populations (as is the case on Curaçao) where large, top predatory fishes have been removed over time (Hoetjes et al. 2002). In addition, fish on the reef were characterized by higher growth rates compared to the bay and channel. Thus, by migrating from the bay and channel to the reef, larger individuals may maximize their fitness by minimizing the ratio of mortality to growth.

Other life history traits may drive movement of larger fish from the bay and channel to the reef. For example, examination of gonads revealed that larger fish on the reef had a significantly higher GSI compared to the channel and bay. Fish remaining in the bay and channel were rarely sexually mature, whereas fish on the reef nearly always were (Grol 2010). Fishes likely migrate to the coral reef to further develop their gonads in order to reproduce and/or release gametes in environments with strong water currents which may serve to disperse larvae away from predatorrich coral reefs (Johannes 1978; Roberts 1997). Thus, nonreef habitats such as mangroves and seagrass beds temporarily alleviate juvenile fish from high predation risk, serving as 'waiting rooms' until they approach maturity and move out of the bay proper to reproduce.

Large-scale, across-ecosystem movements are common for many aquatic taxa, with salmon migrations between freshwaters and the ocean perhaps the most well-known example. As with mangrove and seagrass nurseries in the case of coral reef fishes, freshwater rivers are assumed to provide abundant food or reduced predation threat to salmon parr (Gross et al. 1988; Gibson 1993; Klemetsen et al. 2003). Yet the relative balance of these two factors is difficult to resolve because of the massive spatial scales involved and the myriad factors which differ among the systems. Curaçao provided a unique opportunity to isolate specific mechanisms underlying such movements in a coral reef fish. Replicating our study across species and locations is necessary to evaluate the generality of this pattern, and explore whether reduced predation threat typically is the most important factor explaining the value of nursery habitats for coral reef fishes. Our study showed for a single species that juveniles tend to select habitats in an embayment with lower predation risk over slower growth. Although predation-growth trade-offs are a common phenomenon for various taxa (Werner and Hall 1988; Lima and Dill 1990; Dahlgren and Eggleston 2000; Heithaus et al. 2007; Atkinson et al. 2008; Grol 2010), there are large differences among species in habitat utilization, behavior, or diet, and therefore it is critical to study species with different life histories (review in Faunce and Layman 2009; Nagelkerken 2009). In contrast to the previous studies which focus primarily on within-ecosystem shifts, our species showed a broad-scale, across-ecosystem distribution pattern. Pelagic $H$. flavolineatum larvae did not recruit directly to coral reefs were growth rates were higher, but instead traversed a long distance which is timeand energy-consuming (Stamps et al. 2005) to settle in distinct ecosystems (i.e., embayments with mangroves and seagrass beds) where predation risk was lower.

Elucidating specific mechanisms that give rise to acrossecosystem distribution patterns of organisms has critical implications for assessing how humans may impact ecological and evolutionary dynamics. Collapse of marine fisheries continues largely unabated, and large top predators usually are most affected (Pauly et al. 1998; Worm et al. 2006). Continued alteration of large predator densities in coastal ecosystems may lead to short-term behavioral shifts in response to changing predation risk which may influence current life history traits. Smaller sizes and lower abundances of key top predators on reefs may lead to increased settlement of juveniles directly onto reef habitat, or earlier migration of sub-adult individuals to coral reefs. Such simple behavioral-driven responses ultimately can have profound effects on ecosystem structure and function (Lima and Dill 1990; Heithaus et al. 2007). A recent empirical example on coral reefs demonstrates how varying densities of a large-bodied top predator can trigger trophic cascades solely through behavioral responses of their potential prey (Stallings 2008).

Our data also emphasize the need to maintain connectivity among coastal ecosystems and include effects of seascape composition (Mumby 2006; Pittman et al. 2007; Mumby and Hastings 2008; Munday et al. 2009). For example, pelagic fish larvae which have settled in mangroves and seagrass beds connect nurseries and reefs through their final recruitment to the latter (Nakamura et al. 2008; Verweij et al. 2008), while seascape components such as the amount and proximity of habitat types affect the distribution of juvenile fish observed in mangroves (Pittman et al. 2007) and the function of adjacent coral reef ecosystems (Adams et al. 2006; Mumby and Hastings 2008). At the moment, coral reefs, mangrove forests, as well as seagrass beds, are extensively degraded worldwide as a result of continued human impacts to marine ecosystems (Valiela et al. 2001; Duarte 2002; Gardner et al. 2003; Hughes et al. 2003; Bellwood et al. 2004), leading to loss of benthic structure (Graham et al. 2007; Wilson et al. 2006; Alvarez-Filip et al. 2009). This could dramatically affect the distribution and abundance of fishes utilizing these habitats (Jones et al. 2004; Graham et al. 2007; Wilson et al. 2006; Paddack et al. 2009). Marine protected 
areas are especially important in this context, as they can provide a framework for protection against both overfishing and habitat loss.

Our current understanding of organism movements that link adjacent marine ecosystems remains rudimentary in many ways, and knowledge of the mechanisms that lead to such movements is even less well understood. Continued efforts to identify causal mechanisms of organism movement and ecosystem distribution patterns (e.g., identification of essential fish habitat and predicting impacts associated with environmental change) will provide a more robust foundation for successful conservation and management of marine resources.

Acknowledgments This project was funded by a VIDI grant from the Netherlands Organization for Scientific Research (to I.N.), and supported by a USDA Forest Service post-doctoral fellowship (to A.L.R.), and a NSF OCE \#0746164 (to C.A.L.). We thank C.M. Huijbers, E. van Engelen, N.P. Rossen, A. Thomas, I.E. Schulten, J.H.F. de Brouwer, and L.L. Govers for their support in the field and assistance in the laboratory. This is Centre for Wetland Ecology publication No. 515.

Open Access This article is distributed under the terms of the Creative Commons Attribution Noncommercial License which permits any noncommercial use, distribution, and reproduction in any medium, provided the original author(s) and source are credited.

\section{References}

Adams AJ, Dahlgren CP, Kellison GT, Kendall MS, Layman CA, Ley JA, Nagelkerken I, Serafy JE (2006) Nursery function of tropical back-reef systems. Mar Ecol Prog Ser 318:287-301

Alvarez-Filip L, Dulvy NK, Gill JA, Côté IM, Watkinson AR (2009) Flattening of Caribbean coral reefs: region-wide declines in architectural complexity. Proc R Soc Lond B 276:3019-3025

Aronson RB, Heck KL (1995) Tethering experiments and hypothesis testing in ecology. Mar Ecol Prog Ser 121:307-309

Atkinson A, Siegel V, Pakhomov EA, Rothery P, Loeb V, Ross RM, Quetin LB, Schmidt K, Fretwell P, Murphy EJ, Tarling GA, Fleming AH (2008) Oceanic circumpolar habitats of Antarctic krill. Mar Ecol Prog Ser 362:1-23

Baker R, Sheaves M (2007) Shallow-water refuge paradigm: conflicting evidence from tethering experiments in a tropical estuary. Mar Ecol Prog Ser 349:13-22

Beck MW, Heck KL Jr, Able KW, Childers DL, Eggleston DB, Gillanders BM, Halpern B, Hays CG, Hoshino K, Minello TJ, Orth RJ, Sheridan PF, Weinstein MP (2001) The identification, conservation, and management of estuarine and marine nurseries for fish and invertebrates. Bioscience 51:633-641

Bellwood DR, Hughes TP, Folke C, Nyström M (2004) Confronting the coral reef crisis. Nature 429:827-833

Chittaro PM, Usseglio P, Sale PF (2005) Variation in fish density, assemblage composition and relative rates of predation among mangrove, seagrass and coral reef habitats. Environ Biol Fish $72: 175-187$

Cocheret de la Morinière E, Pollux BJA, Nagelkerken I, van der Velde G (2003) Diet shifts of Caribbean grunts (Haemulidae) and snappers (Lutjanidae) and the relation with nursery-to-coral reef migrations. Estuar Coast Shelf Sci 57:1079-1089
Dahlgren CP, Eggleston DB (2000) Ecological processes underlying ontogenetic habitat shifts in a coral reef fish. Ecology 81:2227-2240

DeVries DR, Frie RV (1996) Determination of age and growth. In: Murphy BR, Willis DW (eds) Fisheries techniques, 3rd edn. American Fisheries Society, USA, pp 483-512

Dorenbosch M, Grol MGG, Christianen MJA, Nagelkerken I, van der Velde G (2005) Indo-Pacific seagrass beds and mangroves contribute to fish density and diversity on adjacent coral reefs. Mar Ecol Prog Ser 302:63-76

Dorenbosch M, Grol MGG, Nagelkerken I, van der Velde G (2006) Seagrass beds and mangroves as potential nurseries for the threatened Indo-Pacific humphead wrasse, Cheilinus undulatus and Caribbean rainbow parrotfish, Scarus guacamaia. Biol Conserv 129:277-282

Dorenbosch M, Grol MGG, de Groene A, Van der Velde G, Nagelkerken I (2009) Piscivore assemblages and predation pressure affect relative safety of some back-reef habitats for juvenile fish in a Caribbean bay. Mar Ecol Prog Ser 379:181-196

Duarte CM (2002) The future of seagrass meadows. Environ Conserv 29:192-206

Faunce CH, Layman CA (2009) Sources of variation that affect perceived nursery function of mangroves. In: Nagelkerken I (ed) Ecological connectivity among tropical coastal ecosystems. Springer, The Netherlands, pp 401-422

Field A (2005) Discovering statistics using SPSS. SAGE, UK

Gardner TA, Côté IM, Gill JA, Grant A, Watkinson AR (2003) Longterm region-wide declines in Caribbean corals. Science 301:958-960

Gibson RJ (1993) The Atlantic salmon in fresh water: spawning, rearing and production. Rev Fish Biol Fisheries 3:39-73

Graham NAJ, Wilson SK, Jennings S, Polunin NVC, Robinson J, Bijoux JP, Daw TM (2007) Lag effects in the impacts of mass coral bleaching on coral reef fish, fisheries, and ecosystems. Conserv Biol 21:1291-1300

Grol MGG (2010) Crossing habitat boundaries: mechanisms underlying cross-habitat utilization by reef fishes. $\mathrm{PhD}$ dissertation, Radboud University Nijmegen, The Netherlands

Grol MGG, Dorenbosch M, Kokkelmans EMG, Nagelkerken I (2008) Mangroves and seagrass beds do not enhance growth of early juveniles of a coral reef fish. Mar Ecol Prog Ser 366:137-146

Gross MR, Coleman RM, McDowall RM (1988) Aquatic productivity and the evolution of diadromous fish migration. Science 239:1291-1293

Haddon M (2001) Modeling and quantitative methods in fisheries. Chapman \& Hall, CRC, USA

Halpin PM (2000) Habitat use by an intertidal salt-marsh fish: tradeoffs between predation and growth. Mar Ecol Prog Ser 198:203-214

Hammerschlag N, Morgan AB, Serafy SE (2010) Relative predation risk for fishes along a subtropical mangrove-seagrass ecotone. Mar Ecol Prog Ser 401:259-267

Haywood MDE, Kenyon RA (2009) Habitat shifts by decapods-an example of connectivity across tropical coastal ecosystems. In: Nagelkerken I (ed) Ecological connectivity among tropical coastal ecosystems. Springer, The Netherlands, pp 229-269

Heithaus MR, Frid A, Wirsing AJ, Dill LM, Fourqurean JW, Burkholder D, Thomson J, Bejder L (2007) State-dependent risk-taking by green sea turtles mediates top-down effects of tiger shark intimidation in a marine ecosystem. J Anim Ecol 76:837-844

Hixon MA (1991) Predation as a process structuring coral reef fish communities. In: Sale PF (ed) The ecology of fishes on coral reefs. Academic Press, USA, pp 475-508

Hoetjes P, Kong AL, Juman R, Miller A, Miller M, de Meyer K, Smith A (2002) Status of coral reefs in the eastern Caribbean: the 
OECS, Trinidad and Tobago, Barbados, the Netherlands Antilles and the French Caribbean. In: Wilkinson C (ed) Status of coral reefs of the world. Australian Institute of Marine Science, Townsville

Hughes TP, Baird AH, Bellwood DR, Card M, Connolly SR, Folke C, Grosberg R, Hoegh-Guldberg O, Jackson JBC, Kleypas J, Lough JM, Marshall P, Nyström M, Palumbi SR, Pandolfi JM, Rosen B, Roughgarden J (2003) Climate change, human impacts, and the resilience of coral reefs. Science 301:929-933

Johannes RE (1978) Reproductive strategies of coastal marine fishes in the tropics. Environ Biol Fish 3:65-84

Jones GP, McCormick MI, Srinivasan M, Eagle JV (2004) Coral decline threatens fish biodiversity in marine reserves. Proc Natl Acad Sci USA 101:8251-8253

Kimura DK (1980) Likelihood methods for the Von Bertalanffy Growth Curve. Fish Bull 77:765-776

Klemetsen A, Amundsen PA, Dempson JB, Jonsson B, Jonsson N, O'Connell MF, Mortensen E (2003) Atlantic salmon Salmo salar L., brown trout Salmo trutta L. and Arctic charr Salvelinus alpinus (L.): a review of aspects of their life histories. Ecol Freshw Fish 12:1-59

Kulmiye AJ, Ntiba MJ, Kisia SM (2002) Some aspects of the reproductive biology of the thumbprint emperor, Lethrinus harak (Forsskål, 1775), in Kenyan coastal waters. West Indian Ocean J Mar Sci 1:135-144

Laegdsgaard P, Johnson C (2001) Why do juvenile fish utilise mangrove habitats? J Exp Mar Biol Ecol 257:229-253

Lima SL, Dill LM (1990) Behavioral decisions made under the risk of predation-a review and prospectus. Can J Zool 68:619-640

Mumby PJ (2006) Connectivity of reef fish between mangroves and coral reefs: algorithms for the design of marine reserves at seascape scales. Biol Conserv 128:215-222

Mumby PJ, Hastings A (2008) The impact of ecosystem connectivity on coral reef resilience. J Appl Ecol 45:854-862

Mumby PJ, Edwards AJ, Arias-González JE, Lindeman KC, Blackwell PG, Gall A, Gorczynska MI, Harborne AR, Pescod CL, Renken H, Wabnitz CCC, Llewellyn G (2004) Mangroves enhance the biomass of coral reef fish communities in the Caribbean. Nature 423:280-283

Mumby PJ, Dahlgren CP, Harborne AR, Kappel CV, Micheli F, Brumbaugh DR, Holmes KE, Mendes JM, Broad K, Sanchirico JN, Buch K, Box S, Stoffle RW, Gill AB (2006) Fishing, trophic cascades, and the process of grazing on coral reefs. Science 311:98-101

Munday PL, Leis JM, Lough JM, Paris CB, Kingsford MJ, Berumen ML, Lambrechts J (2009) Climate change and coral reef connectivity. Coral Reefs 28:379-395

Nagelkerken I (2009) Evaluation of nursery function of mangroves and seagrass beds for tropical decapods and reef fishes: patterns and underlying mechanisms. In: Nagelkerken I (ed) Ecological connectivity among tropical coastal ecosystems. Springer, The Netherlands, pp 357-399

Nagelkerken I, Dorenbosch M, Verberk WCEP, Cocheret de la Morinière E, van der Velde G (2000) Importance of shallowwater biotopes of a Caribbean bay for juvenile coral reef fishes: patterns in biotope association, community structure and spatial distribution. Mar Ecol Prog Ser 202:175-192

Nakamura Y, Sano M (2005) Comparison of invertebrate abundance in a seagrass bed and adjacent coral and sand areas at Amitori Bay, Iriomote Island, Japan. Fish Sci 71:543-550

Nakamura Y, Horinouchi M, Shibuno T, Tanaka Y, Miyajima T, Koike I, Kurokura H, Sano M (2008) Evidence of ontogenetic migration from mangroves to coral reefs by black-tail snapper Lutjanus fulvus: stable isotope approach. Mar Ecol Prog Ser 355:257-266
Ntiba MJ, Jaccarini V (1990) Gonad maturation and spawning times of Siganus sutor off the Kenya coast: evidence for definite spawning seasons in a tropical fish. J Fish Biol 37: $315-325$

Paddack MJ, Reynolds JD, Aguilar C, Appeldoorn RS, Beets J, Burkett EW, Chittaro PM, Clarke K, Esteves R, Fonseca AC, Forrester GE, Friedlander AM, García-Sais J, González-Sansón G, Jordan LKB, McClellan DB, Miller MW, Molloy PP, Mumby PJ, Nagelkerken I, Nemeth M, Navas-Camacho R, Pitt J, Polunin NVC, Reyes-Nivia MC, Robertson DR, Rodríguez-Ramírez A, Salas E, Smith SR, Spieler RE, Steele MA, Williams ID, Wormald CL, Watkinson AR, Côté IM (2009) Recent regionwide declines in Caribbean reef fish abundance. Curr Biol 19:590-595

Pauly D, Christensen V, Dalsgaard J, Froese R, Torres F (1998) Fishing down marine food webs. Science 279:860-863

Peterson CH, Black R (1994) An experimentalist's challenge: when artifacts of intervention interact with treatments. Mar Ecol Prog Ser 111:289-297

Pile AJ, Lipcius RN, van Montfrans J, Orth RJ (1996) Densitydependent settler-recruit-juvenile relationships in blue crab. Ecol Monogr 66:277-300

Pittman SJ, Caldow C, Hile SD, Monaco ME (2007) Using seascape types to explain the spatial patterns of fish in the mangroves of SW Puerto Rico. Mar Ecol Prog Ser 348:273-284

Polis GA, Anderson WB, Holt RD (1997) Toward an integration of landscape and food web ecology: the dynamics of spatially subsidized food webs. Annu Rev Ecol Syst 28:289-316

Post DM, Doyle MW, Sabo JL, Finlay JC (2006) The problem of boundaries in defining ecosystems: a potential landmine for uniting geomorphology and ecology. Geomorphology $89: 111-126$

Roberts CM (1997) Connectivity and management of Caribbean coral reefs. Science 278:1454-1457

Rypel AL, Layman CA, Arrington DA (2007) Water depth modifies relative predation risk for a motile fish taxa in Bahamian tidal creeks. Estuar Coasts 30:518-525

Schreiber S, Rudolf VHW (2008) Crossing habitat boundaries: coupling dynamics of ecosystems through complex life cycles. Ecol Lett 11:576-587

Shulman MJ (1985) Recruitment of coral reef fishes: effects of distribution of predators and shelter. Ecology 66:1056-1066

Stallings CD (2008) Indirect effects of an exploited predator on recruitment of coral-reef fishes. Ecology 89:2090-2095

Stamps JA, Krishnan VV, Reid ML (2005) Search costs and habitat selection by dispersers. Ecology 86:510-518

Stephens DW, Krebs JR (1986) Foraging theory. Princeton University Press, Princeton, USA

Valiela I, Bowen JL, York JK (2001) Mangrove forests: one of the world's threatened major tropical environments. Bioscience 41:807-815

Verweij MC, Nagelkerken I (2007) Short and long-term movement and site fidelity of juvenile Haemulidae in back-reef habitats of a Caribbean embayment. Hydrobiologia 592:257-270

Verweij MC, Nagelkerken I, Hans I, Ruseler SM, Mason PRD (2008) Seagrass nurseries contribute to coral reef populations. Limnol Oceanogr 53:1540-1547

Von Bertalanffy L (1938) A quantitative theory of organic growth. Hum Biol 10:181-213

Werner EE, Anholt BR (1993) Ecological consequences of the tradeoff between growth and mortality-rates mediated by foraging activity. Am Nat 142:242-272

Werner EE, Gilliam JF (1984) The ontogenetic niche and species interactions in size-structured populations. Annu Rev Ecol Syst $15: 393-425$ 
Werner EE, Hall DJ (1988) Ontogenetic habitat shifts in bluegill: the foraging rate-predation risk trade-off. Ecology 69:1352-1366

Wilson SK, Graham NAJ, Pratchett MS, Jones GP, Polunin NVC (2006) Multiple disturbances and the global degradation of coral reefs: are reef fishes at risk or resilient? Global Change Biol $12: 2220-2234$
Worm B, Barbier EB, Beaumont N, Duffy JE, Folke C, Halpern BS, Jackson JBC, Lotze HK, Micheli F, Palumbi SR, Sala E, Selkoe KA, Stachowicz JJ, Watson R (2006) Impacts of biodiversity loss on ocean ecosystem services. Science 314:787-790 